\title{
Legislative Rules in Electoral Authoritarian Regimes: The Case of Hong Kong's Legislative Council
}

\author{
Regina Smyth, Indiana University \\ William Bianco, Indiana University \\ Kwan Nok Chan, University of Hong Kong
}

\begin{abstract}
This article focuses on the manipulation of legislative rules in electoral authoritarian states. Electoral liberalization in authoritarian regimes creates the capacity for opposition forces to win legislative seats, but it does not ensure voice in the policy process. While the literature on institutional authoritarianism points to co-optation, dominant parties, and redistribution as mechanisms to control policy outcomes in authoritarian legislatures, we investigate an additional possibility: that electoral authoritarian regimes (EARs) select legislative institutions that allow free debate and unconstrained voting yet decouple electoral success from policy influence. Our analysis centers on the EAR in Hong Kong and its legislature, the Legislative Council (LegCo). We find that the LegCo's rules of procedure interact with electoral institutions to create considerable roadblocks to opposition initiatives, while at the same time facilitating the enactment of regime policies.
\end{abstract}

n September 2014, Hong Kong's (HK) activists took to the streets against a proposed state-run screening process for chief executive elections and suggestions that a similar process might be used for the Legislative Council, or LegCo (Chan 2016; Ortmann 2015). These events highlight HK's position as an anomaly in theories of electoral authoritarian regimes (EARs). Previous work shows that durable EARs combine electoral liberalization and delegation of power to elected officials with mechanisms that preserve the regime's control over legislative proceedings, such as screening procedures for candidates or a hegemonic state party. The HK regime lacks these mechanisms yet appears to be in firm control of the LegCo. Has the regime accepted the risk of the possible future election of a hostile legislative majority, or does something else preserve its veto over LegCo proceedings?

Our premise is that theories of how EARs preserve their status as legislative veto players (Tsebelis 2002) should move beyond electoral arrangements to consider how these regimes use legislative rules to maintain their hold over policy. While some EARs use constitutional arrangements such as bicameralism (Tsebelis and Money 1997) to delay, weaken, or block wayward legislative coalitions, little work has focused on the chamber rules that determine how these legislatures operate. Such rules, we argue, can have a profound effect on an EAR's control over policy.

To establish this point, we analyze the interaction between two features of HK's system: (a) the practice of electing LegCo members from a combination of geographic districts and socalled functional seats and $(b)$ the procedure we label as split voting, whereby proposals offered by legislators require majorities from both geographic and functional seats to be enacted but government proposals only require a chamber majority. As a result of these procedures, member-initiated measures can be rejected even when they receive the support of a chamber majority, but government-initiated measures can secure passage with a chamber majority even if a majority of functional constituency (FC) or geographical constituency (GC) members oppose passage. In this way, LegCo procedures are key to the survival of HK's EAR.

More generally, these findings suggest the need to appreciate how EARs differ in their broader representative structures. While a willingness to hold meaningful elections distinguishes EARs from other authoritarian regimes, EARs can vary in terms of the restrictions they place on candidates

Regina Smyth is an associate professor of political science at Indiana University, William Bianco (corresponding author; wbianco@indiana.edu) is a professor of political science at Indiana University, and Kwan Nok Chan is an assistant professor of politics and public administration at the University of Hong Kong.

Data and supporting materials necessary to reproduce the numerical results in the article are available in the JOP Dataverse (https://dataverse.harvard .edu/dataverse/jop).

The Journal of Politics, volume 81, number 3. Published online April 25, 2019. http://dx.doi.org/10.1086/703068

(C) 2019 by the Southern Political Science Association. All rights reserved. 0022-3816/2019/8103-0009\$10.00 
and elections, their use of nonmajoritarian legislative rules, and the interactions between these two kinds of mechanisms. An EAR that appears relatively liberal from one perspective may look quite different when considered in total. Particularly in complex societies, where EARs face threats from opposition forces as well as from dissident regime elements, the details of legislative procedure may play a crucial role in determining how citizen demands are translated into government policy.

Finally, our findings explain the HK regime's recent attempt to impose litmus tests on the chief executive and LegCo candidates. Our work suggests that this move may be driven by the recent electoral successes of progovernment LegCo candidates. Because these gains are concentrated in geographic LegCo districts (progovernment candidates have always won the bulk of functional seats), they are narrowing the policy differences between legislators representing functional and geographic seats - the same differences that make split voting effective in maintaining state control. With this backstop in danger, the regime appears to see nomination controls as an alternate strategy for preserving its position.

\section{AUTHORITARIAN INSTITUTIONS AND REGIME STABILITY}

EARs feature regimes that have no intention of ceding control of the state but that nonetheless hold regular elections to a legislature or other political offices. Many studies show that EAR longevity is enhanced by the combination of electoral liberalization and a legislature invested with law-making powers (Boix and Svolik 2013; Gandhi 2008; Geddes 1999; Ghandi and Przeworski 2007; Levitsky and Way 2002; Svolik 2012; Wright 2008). ${ }^{1}$ Elections where candidates are free to campaign and votes are counted as cast provide information on true social preferences and transform the legislative arena into a venue for debating new policies, highlighting bureaucratic malfeasance, and helping the regime to anticipate challenges, respond to new problems, and evaluate existing policies (Magaloni 2008; Wintrobe 1998). Electoral competition can institutionalize succession rules and force repeated interactions among political elites, facilitate political bargains by creating a publicly observable signal of the regime's commitment to such bargains (Boix and Svolik 2013; Svolik 2012), and generate a legislature populated by professionalized politicians whose expertise and skills lead to more effective legislation and oversight (Truex 2013).

1. Recent studies (Gates et al. 2016; Strøm et al. 2016) on institutionalized power-sharing arrangements in post-civil war societies arrive at similar conclusions: such arrangements are more likely to persist when they constrain the actions of the dominant party or group. In the context of EARs, these findings support the idea of a positive relationship between electoral liberalization and EAR longevity.
However, having ceded significant control over both election outcomes and legislative proceedings, EARs face a new problem: they must ensure that the winners of elections, once ensconced in the legislature, cannot contravene regime policy goals. The EAR can sustain its position as a veto player (Tsebelis 2002), by stripping the legislature of significant decisionmaking power or making threats against renegade legislators, but these moves work against all of the benefits described earlier. One well-documented solution is to form a hegemonic or dominant state party (Brownlee 2007; Geddes 2005). Dominant state parties such as the Partido Revolucionario Institucional (PRI) in Mexico (1929 to about 2000) and the Kuomintang (KMT) in Taiwan (1950 to about 2000) recruit, fund, and mobilize support for candidates who share the regime's goals. After the election, these parties provide disciplinary mechanisms that motivate legislators to support regime goals during debates and votes, thereby ensuring that the regime enjoys the benefits of free elections without risking its control over policy or its position in power. These parties also afford political leaders control over the state bureaucracy through appointments of ministers and senior managers. EARs can also require would-be candidates to gain approval from state parties or other regime-controlled bodies, weeding out potential regime opponents before the campaign begins. For example, candidates to the Cuban National Assembly of People's Power are nominated by local organizations or by electoral committees, both firmly controlled by the Communist Party of Cuba. ${ }^{2}$

\section{MECHANISMS OF EAR CONTROL: LOOKING BEYOND ELECTORAL MECHANISMS}

While it is easy to see how a building hegemonic party or implementing controls on candidacy would help to preserve an EARs veto over legislative deliberations, it is also easy to imagine situations in which these mechanisms would prove insufficient. For one thing, hegemonic parties are not inevitable outcomes of controlled electoral competition. Moreover, cases such as Korea, Mexico, and Taiwan illustrate that changes in citizen demands, international pressures, or a dropoff in an EAR's popularity due to incompetence or corruption can abruptly change the legislative balance of power in favor of the opposition or dissident regime elements.

Other EARs, such as in HK, simply lack hegemonic parties because of other constraints. While the formation of a regional hegemonic party would seem the obvious way to control the LegCo, such a development is problematic because it would create an alternate center of power to the Chinese Communist

2. For details, see the articles in the 2016 special issue of Socialism and Democracy, vol. 30, no. 1 . 
Party that controls the People's Republic. This reality sharpens the problem for HK's EAR: while it can normally count on votes from the $\mathrm{DAB}$, smaller parties, and independents, it has no way to guarantee this support. For example, the regime's proposals to screen chief executive candidates (the proposals that triggered the Umbrella Revolution) were ultimately defeated by a large margin in the LegCo, as many nominal regime allies failed to coordinate to stall the vote and caused considerable embarrassment to the regime (Chan 2016). We argue that this inability to determine who gets elected to the LegCo or how they behave in office drives HK's EAR to manipulate voting rules as a way of preserving its veto over LegCo outcomes.

At the level of broadscale constitutional provisions, there are many examples of legislative arrangements that sustain an EAR's veto power. For example, the 45-seat Advisory Council in Qatar is composed of 30 members elected by the people, with an additional 15 members appointed by the emir (Ramady 2013). Enacting legislation requires a two-thirds majority and the emir's consent-giving the emir a firm veto over the council's actions. Moreover, the emir's appointees can prevent the emir from having to cast unpopular or controversial vetoes by voting as a bloc to defeat such proposals in the first place. Another strategy used by the Cambodian and Russian EARs involves a bicameral legislature (Tsebelis and Money 1997), with the lower house popularly elected and the upper house firmly controlled by the regime and able to block legislation enacted by the lower house. $^{3}$ Other EARs (e.g., China and Cuba) implement veto power by using standing committees to control the agenda and manage policy for a largely part-time chamber.

Building on these results, we argue that chamber-level rules of procedure deserve additional scrutiny to assess their role in preserving an EAR's veto power. Countless studies of legislatures in democracies have shown how policy outcomes are shaped by manipulation of legislative procedures (Gamm and Huber 2002). If we only explain EAR survival and control over policy as a consequence of electoral or party-based mecha-

3. The Cambodian EAR has formed a state party, the Cambodian People's Party (CPP). In Cambodia's Parliament, the National Assembly (lower house) is elected in multimember districts using party-list proportional representation, while the composition of the Senate (upper house) is determined by local council elections and a small number of royal appointments. However, most local councilors are members of the CPP. As a result, while the CPP did not win a majority of seats in the last National Assembly election, it dominated elections to the Senate, meaning that even if the opposition manages to build majority support in the Assembly for a reform proposal, there is little chance that it will survive Senate consideration. Russia's United Russia EAR exercises similar control through a (nominally) popularly elected Duma and a Federation Council appointed by regional governors, virtually all of whom are loyal to United Russia. nisms, our accounts may be missing a crucial explanatory variable. $^{4}$

Focusing on legislative rules would also help to identify the precise role that legislative interactions play in different EARs. Gandhi and Przeworski (2007; see also Gandhi 2008) argue that EARs structure legislative proceedings to provide a forum for the opposition to voice concerns and share information, without creating a threat to regime stability. Under this scenario, the opposition accepts limitations on legislative power in return for a role in debating policy options. However, Svolik (2012) suggests that EAR legislatures can provide regime elements with the ability to block an autocratic leader. Our focus on legislative rules and their impact on policy making can help to distinguish EARs that use the legislature for information provision from EARs for which the legislature is a mechanism of elite control.

The HK EAR and its LegCo is an ideal venue to explore our hypothesis about legislative rules. The LegCo is relatively powerful: on a nine-point scale of legislative powers (Fish and Kroenig 2006), the chamber's ranking is comparable to many legislatures in democratic systems, including South Korea, Brazil, and France. ${ }^{5}$ LegCo elections are free of fraud or intimidation of opposition candidates and voters. However, HK's EAR does not have a hegemonic state party, has not (up to now) moved to vet LegCo candidates, and does not appear to coopt legislators with financial or other rewards. Thus, the HK EAR is not using any of the canonical EAR strategies for preserving control over the legislature, even though scholars of HK politics have long argued that the chamber is firmly subordinate to the executive branch (Lau and Kuan 2000; Scott 2000). How does HK's EAR preserve this outcome?

\section{THE HONG KONG EAR}

HK's EAR emerged from the British colonial period and was institutionalized in the "one country, two systems" bargain that transferred political control from the UK to the People's Republic of China. A crown colony until the handover to

4. Moreover, among the various control mechanisms discussed here, legislative rules are the most likely to be little-known and poorly understood by the average citizen, possibly allowing an EAR to control policy making without arousing public ire or giving the opposition an issue it can use in the next election.

5. The variables used to construct the legislative powers scale include whether the legislature can replace the chief executive, whether it can vote no confidence in ministers, whether legislators can serve as ministers, whether the executive can rule by decree, whether legislators can amend the constitution, whether legislative enactments are subject to veto, whether all legislators are elected rather than appointed, whether budgets approved by the legislature are subject to impoundment, and whether there are regular legislative sessions. 
China in 1997, HK is unique in that the authoritarian government is dependent not only on citizen support but also on the ongoing approval of the central government in Beijing. Beijing's policy toward HK has been motivated by both the fear of a "demonstration effect" for dissidents in mainland China (Ma 2011) as well as the vulnerability of the city to political interference by foreign interests (Sing and Tang 2012). Beijing "wants the legitimacy of an electoral democracy, but does not want to give up control and accept the uncertainty that elections bring" (Ma 2011, 66). These constraints explain the absence of a hegemonic state party in $\mathrm{HK}^{6}{ }^{6}$ While HK's progovernment forces (led by the Democratic Alliance for the Betterment and Progress of Hong Kong [DAB]) are nominally Beijing's allies, their policy preferences are not necessarily or inevitably identical. A hegemonic state party might provide a mechanism for blocking Beijing's future policy or constitutional initiatives. Moreover, even if such disagreements did not exist, the Beijing government would prefer to keep all political organizations in HK weak and disorganized, to reinforce the perception that party politics is no viable alternative to centralized state control, both in HK and in China itself.

The outlines of HK's government were codified in the quasiconstitutional document known as the Basic Law (Scott 2000). While article 68 of the Basic Law contained provisions for the "gradual and orderly progress" toward "the election of all the members of the Legislative Council by universal suffrage," compliance with these goals was left to HK's government. Almost 20 years after the handover, the current HK government features a strong chief executive who is selected by Beijing loyalists in a small electoral college (Scott 2000). The Fifth Council, elected 2012 and serving until 2016, is composed of 70 members, 35 elected from five multimember districts (GCs) and 35 elected by designated professional and business sectors (FCs, including five seats for the so-called District Council constituency that are voted on by $\mathrm{HK}$

6. The government has argued that party politics would give rise to populist agendas, threatening HK's market-oriented and probusiness policy (Lau and Kuan 2002). More importantly, Beijing sees political parties as potential "vehicles for the mobilization of the anti-communist passions of Hongkongers" (Lau and Kuan 2002, 1012). Centripetal electoral rules ensured that seats would be dispersed among small parties that remain weak (Ma and Choy 1999). Most of the dozen or so parties active in the LegCo at any given time tend to be transitory candidate-centered organizations (Leung 1997). Weak parties limit the potential for collective action within the legislative body, protecting Beijing from the emergence of strong opposition leadership or the potential of a cross-factional alliance demanding regional autonomy. Party development is also limited by the rule requiring the chief executive elect to break off any existing party affiliation before taking office and the prohibition on parties developing ties with foreign political organizations, arrangements inserted into the Basic Law on Beijing's demand (Lau and Kuan 2002).

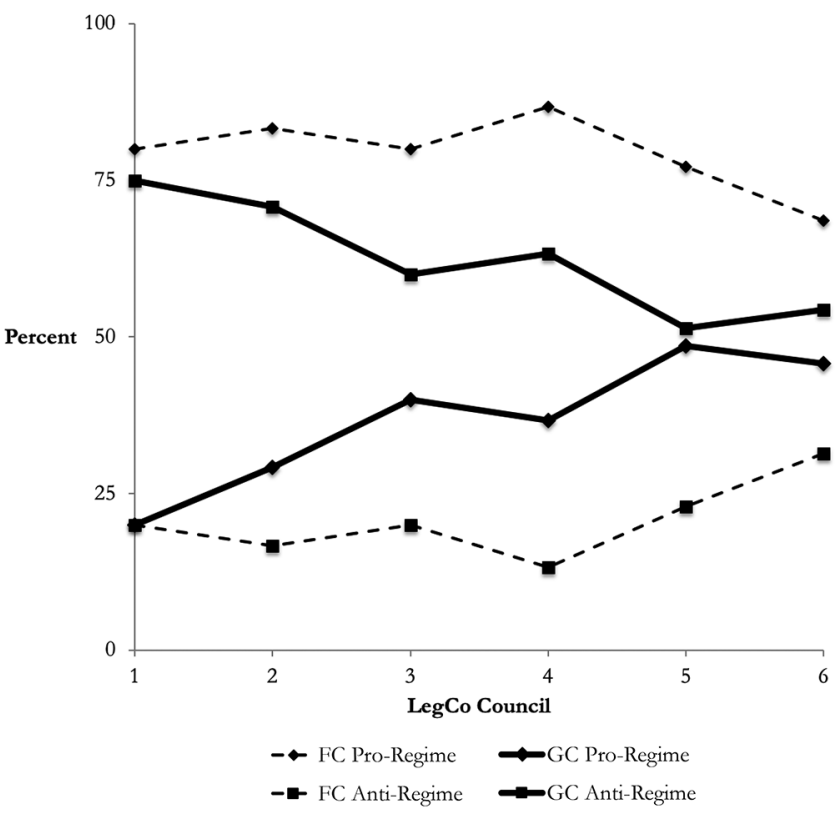

Figure 1. Geographic and functional seats

residents not otherwise represented by an FC). ${ }^{7}$ This structure increases the range of interests in the LegCo and, in particular, ensures the representation of probusiness and pro-China interests (Loh 2006).

Figure 1 shows the number of proregime and opposition legislators elected over time to the LegCo: progovernment candidates dominate FC seats, while opposition candidates have gradually lost ground in GC contests, although all elections have produced a significant number of legislators who openly oppose the government's policy initiatives. ${ }^{8}$ These results reflect electoral rules designed to increase the number of candidates and minimize incentives for candidate investment in strong party organization. The GC contests involve party-list-proportional representation in multimember districts using the largest remainder method and the Hare quota and a low electoral threshold. This system lowers barriers to entry and encourages large numbers of parties - and therefore a large number of candidates - to enter the race, and it creates a high level of disproportionality that favors the better-organized progovernment candidates. ${ }^{9}$ FCs use either

7. The appendix provides details on the GC and FC seats in the 2012 LegCo elections, showing how the posthandover legislative mandate has changed since 1997. Election Committee seats were filled by candidates chosen by a body of mostly business-friendly and pro-Beijing electors.

8. Our classification of legislators into of pro- and antigovernment groups is based on their voting behavior, particularly on measures related to democratization and universal suffrage. We discuss this measure in detail later in the article. Our characterization is consistent with other analyses of HK politics (Scott 2000).

9. Lower electoral thresholds also enhance the value of state resources in contesting the GCs' affording the government significant advantage over the opposition. State resources can be channeled to a relatively limited 
first-past-the-post or preferential elimination rules that create significant barriers to entry and dissuade marginal challengers. FC rules also embody significant restrictions on candidacy (Young and Law 2004) that undermine political parties' capacities to field appropriate candidates. FC constituencies represent relatively small numbers of voters, enhancing the value of personal connections and networks and weakening the viability of party-sponsored and opposition candidates (Lau and Kuan 2002).

In the 2012 elections, this combination of rules produced a LegCo with a relatively large number of parties (18, including 12 with one or two officeholders) and a significant percentage of independents $(12 / 70, \sim 17 \%)$. A third of FC seats were uncontested. The party closest to the regime, the DAB, holds less than $20 \%$ of LegCo seats. These outcomes are exactly what we would expect given the electoral institutions described here and are consistent with the regime's overarching goal of preventing the formation of political organizations that might challenge Beijing's control over the territory.

Given the disparity of FC and GC results, it is no surprise that opposition forces often call for the FC to be eliminated. Proregime forces typically respond that the FC should be retained because of the need to keep different interests and policy preferences represented - something that a LegCo dominated by GC members might not achieve (Scott 2007; Young and Law 2004). More importantly, as we demonstrate later, FC seats play a crucial role in the state's efforts to control LegCo proceedings. The point is not that FC seats provide a secure base of regime support, although they currently do. Rather, as we show in the next section, LegCo voting rules exploit the differences in the kinds of candidates elected to GCs and FCs in a way that preserves the regime's status as a veto player in the legislature.

\section{LEGISLATIVE RULES AND LEGCO OUTCOMES}

At first glance, the HK's veto power is the product of agenda control, specifically the regime's monopoly power over LegCo proposals. ${ }^{10}$ In particular, while LegCo rules give the government the power to initiate proposals, they also stipulate that members may not introduce a proposal that affects public expenditure or that, in the opinion of the LegCo

proportion of the constituency to win seats for progovernment forces. Likewise, government resources can be mobilized to serve as campaign resources for state-sponsored candidates. As a result, the currency of electoral competition has shifted from universalist policies such as economic growth versus democratization to patronage (Ma and Choy 2003).

10. We use the term "measure" to describe anything voted on during LegCo proceedings. Following usage in the LegCo, proposals are measures that alter government policies or budgets, while motions are measures that have no policy effects. president, would affect the structure or operation of government agencies. Exceptions require the written consent of the chief executive, which has never happened (Legislative Council Secretariat 2008). However, LegCo members are permitted to propose amendments to government proposals without germaneness restrictions. ${ }^{11}$ Thus, members are essentially guaranteed debate and a vote on whatever policy changes they wish to offer, as long as they frame them as amendments to government-sponsored proposals. LegCo members can also offer motions or amendments to motions, with the restriction that these measures cannot alter policy or spending. Even so, motions allow proposers to signal their positions on controversial issues, force opponents to reveal their positions, or highlight governmental corruption, policy failures, or other unpopular outcomes. ${ }^{12}$

Our investigation shows that the key to the HK regime's control over LegCo proceedings lies in the voting procedures used on government and member-sponsored measures. LegCo measures offered by the government are voted on using majority rule - they are enacted if they receive a majority of yea votes (abstainers and those present but not voting are counted as nays, while the votes of absent members do not count) from the chamber as a whole. However, measures offered by LegCo members are decided by a procedure we label split voting: votes are tallied separately for FC and GC members, and passage requires a majority of yea votes from members in each of the two groups. Put another way, memberinitiated measures can be rejected even when they receive the support of a chamber majority, but government-initiated measures can secure passage with a chamber majority even if a majority of FC or GC members oppose passage.

This combination of legislative rules creates an important paradox. At one level, the LegCo is the model of an open, democratic legislature. LegCo members can offer motions or

11. A referee asked why the HK regime does not impose additional restrictions on proposals (such as a closed rule) as to further disempower the opposition. The answer, we suspect, is that split voting restrictions are sufficient, at least for the moment, and wholesale restrictions on members' proposal power might engender citizen protest, which the regime prefers to avoid if it can.

12. Another possibility is that LegCo members could use amendments as a way to delay government initiatives. Ma $(2007,123)$ reports that the legislative process has become more "viscous" as lawmakers spend more time scrutinizing and deliberating bills in the hope that the government will trade concessions for time. Individual cases reveal that high legislative viscosity and political miscalculations on the part of the government can lead to serious public opposition to government bill proposals. Indeed, at two times in the fourth and fifth LegCo sessions in our data, a small number of legislators proposed hundreds of amendments to government bills, including those for budget appropriations, although eventually the presiding officer ended debate and moved for a vote on the government proposal, which was enacted. 
amendments, there are no official or unofficial restrictions on the content of these measures, votes are counted as cast (and cast without coercion), and the full record of LegCo proceedings is publicly available. Moreover, the split voting procedure is arguably a variation on bicameral legislative institutions that are used in one form or another by many democracies. However, as we show in the next section, the split voting procedure interacts with electoral institutions in a way that gives HK's EAR a veto over legislative policy changes. In this way, split voting in the LegCo is a canonical example of how an authoritarian regime can create legislative rules that allow for open debate in the chamber and even the theoretical possibility of opposition success while maintaining firm control over the process.

\section{THE UNCOVERED SET AND LEGCO OUTCOMES}

Our analysis of the impact of split voting in the LegCo relies on the uncovered set (UCS), an analytic tool that identifies the possible outcomes of majority rule decision making given data on the preferences held by decision makers (Cox 1987; McKelvey 1986; Miller 1980; Shepsle and Weingast 1984). ${ }^{13}$ Our analysis describes preferences held by each LegCo member using a two-dimensional spatial model: one dimension measures preferences regarding democracy and universal sovereignty, while the other captures opinions regarding economic liberalism and regulation. We locate an ideal point for legislators in this two-dimensional space on the basis of their roll call voting behavior in the first through fifth LegCo sessions, using the Optimal Classification technique (Poole 2000). Given this specification, the UCS is a region of points in the two-dimensional space. The importance of the UCS is in its ability to predict legislative outcomes given endogenous (open)

13. As Shepsle and Weingast $(1984,69)$ put it, "it appears that the relevant set of possible outcomes for open-agenda processes with sophisticated voters is UC(X) [the uncovered set].” Similarly, Cox (1987, 419) argues, "If one accepts the . . assumption that candidates will not adopt a spatial strategy $\mathrm{Y}$ if there is another available strategy $\mathrm{X}$ which is at least as good as $\mathrm{Y}$ against any strategy ... and is better against some of the opponent's possible strategies, then one can conclude that candidates will confine themselves to strategies in the uncovered set." It should be noted that these results are sensitive to assumptions about how the legislative agenda is constructed and that the prediction pertains only to final outcomes, not the intermediate outcomes that receive majority support before the final outcome is chosen. The LegCo's open rule procedures are consistent with Shepsle and Weingast's assumption of open or endogenous agendas, meaning we are on safe ground when using the UCS to predict legislative outcomes. That said, works by Duggan (2006) and Penn (2009) confirm that outcomes might be sensitive to allocations of agenda power, suggesting that some allocations in other legislatures, particularly if exogenous, might support the attainment of outcomes outside the UCS. Even so, our use of the UCS is justified by the many empirical and experimental applications cited in the main text. agendas, such as exist in the LegCo: previous work (Shepsle and Weingast 1984) shows that regardless of where the "status quo" is when voting begins, there is a simple two-step (amendment) agenda that yields some point in the UCS as its final outcome. Thus, supporters of outcomes in the UCS can secure these outcomes using relatively simple agendas and, moreover, can defend them against attempts to overturn them by opponents who propose outcomes outside the UCS. This logic suggests that the set of enactable proposals that may be chosen by legislative bodies is restricted to the UCS. Thus, if we know which outcomes are in the UCS, we know what is possible in a legislature - what might happen when proposals are offered and voted on.

Given estimates of LegCo ideal points, we can locate the UCS for any LegCo session or for any subset of members in a particular session (such as legislators holding geographic or functional seats) using a grid-search technique (Bianco, Sened, and Jeliaskov 2004). ${ }^{14}$ The use of the UCS as a predictor of final outcomes has been validated using experiments (Bianco et al. 2006, 2008) and real-world data (Jeong, Miller, and Sened 2009; Kam et al. 2010; Smyth et al. 2011). For a review of the entire research program, see Bianco et al. (2015).

We use the UCS to verify our suspicions that split voting in LegCo, coupled with the differences in preferences held by FC and GC legislators, creates a barrier against policy change by LegCo members. Recall that regime-sponsored proposals or amendments are enacted by a majority vote of the chamber, while member-sponsored amendments require concurrent majorities for geographic and functional seats. Thus, the critical question is whether the UCSs for geographic and functional legislators overlap - if they do not, then it is impossible for members to create a final outcome (such as an amendment to a government proposal) that shifts government policy, as any measure that is enactable by geographic legislators is unenactable when voted on by legislators holding functional seats and vice versa. ${ }^{15}$

14. A referee noted that spatial models such as assumed in our analysis and in Shepsle and Weingast (1984) specify an infinite number of outcomes, but our grid-search procedure transforms the game into a finite-outcome gridded version. Thus, calculated UCSs are an approximation of the true UCS. However, as McKelvey (1986) suggests, a grid search is really the only option-in general, calculating the true UCS is an NP-hard problem. However, Bianco et al. (2004) find that the results of the grid search converge to the true UCS as the grid size becomes finer and finer. Additional support for this technique can be found in the experimental and empirical results cited earlier.

15. Our argument here concerns proposals and amendments that have policy consequences. As noted earlier, members can also offer motions or amendments to motions, which by definition cannot affect expenditures or government policy. For these measures, the various UCSs for the LegCo (which are a function of members' policy preferences) might not constrain legislative outcomes. We test this conjecture in our empirical analysis. 
Figure 2 shows ideal points and UCSs for the current (Fifth Session, elected 2012) LegCo. In the figure, each legislator's preferences are represented as a point in the two-dimensional space. ${ }^{16}$ Legislators' positions on the $x$-axis describe their preferences regarding democratic reform and universal suffrage in $\mathrm{HK}$ - legislators on the left-hand side (opposition) favor less control by Beijing and expanding the franchise, while legislators on the right-hand side (proregime) favor a restricted franchise. The $y$-axis gives a legislator's views on issues relating to economic liberalism, such as the provision of social benefits or the emphasis on redistribution.

This distribution of ideal points confirms the overall fragmentation of the LegCo party system. LegCo members are divided according to their beliefs about democratic reform, with the progovernment DAB and its allies favoring the Beijing position of tighter controls on political outcomes in HK, and the Civic Party, Democratic Party, and other "pan-democrats" favoring moves toward universal suffrage and less control from Beijing. However, there is considerable disagreement within the progovernment faction. Members of the Liberal Party hold strong promarket positions, while members of the $\mathrm{DAB}$ and various small parties and independents favor higher levels of government intervention and prolabor regulation.

Figure 2 also shows the UCSs for FC and GC members, along with the UCS for the chamber as a whole. The GC UCS shows the set of measures (relatively prodemocratic reforms, relatively liberal on social policy) that would receive a majority of yea votes from GC members. Similarly, the FC UCS shows the set of measures (less sympathetic to democratic reforms and redistribution than in the case of the GC's UCS) that would gain majority support from FC members. However, these two UCSs do not overlap-meaning that it is impossible to devise a measure that will attract majority support simultaneously from both groups. This situation is created by the difference in preferences between FC and GC members - the UCSs capture the impact of these differences at the level of majority coalitions. Coupled with the requirement for split voting, the distance between the two UCSs should make it all but impossible for LegCo mem-

16. One concern with using optimal classification to estimate legislators' ideal points (e.g., Bateman and Lapinski 2016; Spriling and McLean 2006) is that insofar as legislators are strategic, their votes might constitute a biased signal of their underlying preferences. While this concern is impossible to eliminate at a theoretical level, our ideal point estimates are consistent with descriptive studies of the LegCo. Ma (2007) divides LegCo members on two dimensions (pro-China vs. prodemocratization and prograssroots vs. probusiness) that are essentially the same as ours. Ma's work also places the parties in locations that are consistent with the recovered ideal points of party members. Thus, while agreeing that measuring preferences based on votes can be problematic, these issues do not arise for our analysis.

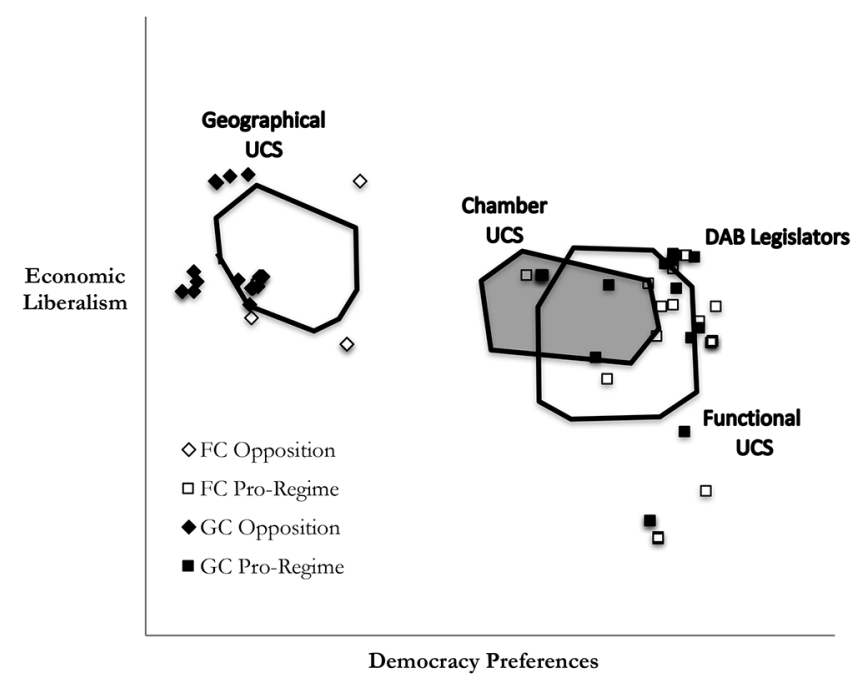

Figure 2. LegCo ideal points and uncovered sets

bers to enact measures that change government policies or budgets.

Figure 2 also shows the UCS for the entire LegColabeled the chamber UCS. This area contains measures that are enactable when the chamber votes on the measure using simple majority rule - that is, the procedure used for government-sponsored measures. Note that the right-hand edge of the chamber UCS is close to the preferences of legislators from the proregime $\mathrm{DAB}$. In other words, given member preferences and LegCo voting procedures, figure 2 shows that the regime's preferred policies and spending proposals are enactable, in that they lie in the chamber UCS. This disparity between the constraints faced by the government and by LegCo members is consistent with the logic of EAR, that electoral and legislative institutions will be chosen to allow unfettered elections while preserving the state's veto over policy outcomes.

One objection to this argument is the possibility that LegCo members could coordinate their votes to enact compromise proposals whose outcomes were in between the GC and FC UCSs. As a referee suggested, given a bad-enough status quo, a majority of legislators would prefer such a compromise proposal, even though it yielded a covered outcome. There are three problems with this conjecture. First, as we show later, there is no evidence of such compromises in our roll call data. Second, given the open-rule nature of LegCo proceedings, any compromise motion would be vulnerable to amendments offered by FC or GC legislators. Third, proregime legislators face little incentive to agree to compromise proposals. Give the distribution of ideal points shown in figure 2, even if the status quo is universally disliked, the regime can offer proregime legislators a proposal that yields an outcome that is close to their ideal - a proposal, moreover, that can be enacted with a 
simple chamber majority. ${ }^{17}$ Thus, proregime legislators have no reason to agree to covered compromises, as they can get better outcomes from the regime.

\section{THE POLICY HYPOTHESIS}

Based on our analysis of LegCo preferences and institutions, our hypothesis predicts a sharp difference in the probability of enactment for policy-relevant LegCo measures (proposals and amendments to proposals) offered by the government and by LegCo members:

Policy Hypothesis (PH). Given the current disparity in preferences between FC and GC legislators, the probability that a LegCo proposal or amendment to a proposal is enacted will be high $(\sim 1)$ for governmentsponsored measures and low $(\sim 0)$ for membersponsored measures.

In other words, we expect that the government will always be able to enact its preferred proposals - as shown in figure 2 , the LegCo chamber UCS (which defines the set of outcomes that can be obtained through majority rule) almost touches the ideal points of legislators from $\mathrm{DAB}$, which is a plausible proxy for the government's preferences. Thus, in equilibrium, the government can offer proposals or amendments to proposals that are close to their ideal and yet enactable given majority rule voting in the LegCo, resulting in high rates of enactment for these measures. In contrast, proposals or amendments to proposals offered by LegCo members must receive majority support from both FC and GC legislators. However, given the current distribution of LegCo members, the FC and GC UCSs (which define the set of outcomes that majorities in each group will support) do not overlap — meaning anything that is enactable in one group is not enactable in the other. Given these constraints, members of the current LegCo should be unable to enact any proposals or amendment to proposals (subject to the vote trading caveat mentioned earlier).

\section{ANALYZING LEGCO ENACTMENTS}

Our test of the $\mathrm{PH}$ focuses on measures that were voted on during the first half of the fourth (March 2008-December 2010) and the fifth (March 2012-July 2014) LegCo sessions. We use a multivariate analysis to assess the difference in enactment rates between the four types of LegCo measures: proposals, amendments to proposals, motions, and amendments to motions. The unit of analysis is a recorded vote in the

17. Formally, the logic of the UCS predicts that while a covered outcome might receive majority support at some point in the voting process, it will not emerge as a final outcome.

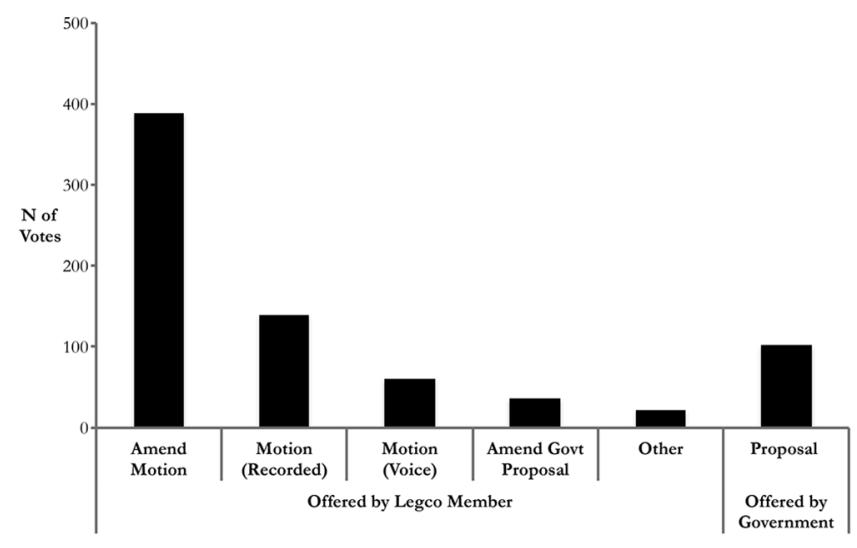

Figure 3. Types of votes

LegCo on a single measure, with the dependent variable equaling 1 for enacted measures and 0 for defeated measures. Figure 3 gives statistics on the different kinds of measures in our data. ${ }^{18}$ The most common case (about 70\%) involves votes on motions offered by LegCo members or amendments to these motions. About a quarter of these measures are decided using voice votes. LegCo members also offer a number of amendments to government proposals. The government-proposed measures include appropriations bills and substantive proposals, all of which involve recorded votes. In all, opposition legislators offer about $50 \%$ of the measures in figure 3 (including virtually all of the amendments to proposals), with proregime legislators offering about $30 \%$ and the government about $20 \%$.

Table 1 defines our exogenous variables and gives predictions about the sign of the parameters for each variable. The Government Proposal variable equals 1 for proposals or appropriations offered by the government and 0 otherwise; the $\mathrm{PH}$ implies that the parameter for this variable should be positive and significant. ${ }^{19}$ The next variable, Amendment to Government (also 1/0), accounts for cases in which a LegCo member offers an amendment to a government proposal. Here, the $\mathrm{PH}$ predicts a negative parameter. Next, there are two variables that describe the preferences of the proposer of a nongovernment motion or amendment: Opposition, which equals 1 for regime opponents (defined on the basis of their NOMINATE scores), or Distance to DAB, which is the distance between the proposer's ideal point and the average ideal point of DAB legislators. This latter variable is included to control for the possibility that the prospects for enacting a

18. As noted earlier, we exclude opposition motions offered as part of filibuster strategies.

19. Note the default or omitted type of measure is member-sponsored motions. We exclude voice votes from the analysis-since all measures decided using voice votes were enacted, there is no variation to analyze. 
Table 1. Exogenous Variables in LegCo Analysis

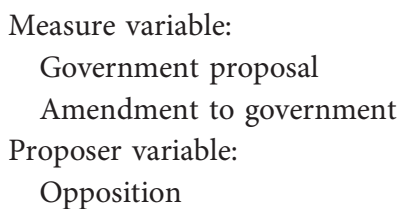

Distance to DAB

Control variable: Amendment to motion Other
Government-sponsored proposal or appropriations bill Amendment to government-sponsored measure

Proposer of motion or amendment is member of LegCo opposition

Distance between ideal point of proposer and average ideal point of $\mathrm{DAB}$ members

Amendment to motion Miscellaneous LegCo measure (e.g., shorten division bells)
$+$

$-$

$-$

$-$

NS NS

Note. LegCo $=$ Legislative Council; DAB $=$ Democratic Alliance for the Betterment and Progress of Hong Kong; NS $=$ not significant .

measure might be higher for progovernment legislators. Finally, we include two 1/0 control variables, accounting for votes involving amendments to motions and a few miscellaneous votes.

Table 2 gives the parameters and significance levels for two logit regressions with the $1 / 0$ enactment measure as the dependent variable. Column 1 contains our preferred model; column 2 substitutes the Opposition variable for the Distance to DAB variable. The signs, magnitudes, and significance of the parameters across the two estimations are remarkably stable and consistent with our hypothesis.

Figure 4 interprets these parameters, showing the predicted probability of enactment for different types of LegCo measures. This figure is constructed using the parameters in column 1 of table 2, comparing the government's success rate with two hypothetical LegCo members: a member of the pro-opposition Democratic Party and a member of the proregime DAB (the ideal points are the average for each party). Consistent with the $\mathrm{PH}$, the analysis shows that government proposals have a high probability of enactment, while member-sponsored amendments to these proposals have an extremely low probability of enactment. These results confirm our suspicions about the impact of LegCo procedures on policy outcomes - and on the HK EAR's ability to control these outcomes consistent with its policy goals. ${ }^{20}$

Figure 4 also reveals variation in the predicted probability of enactments of motions and amendments to motions: about .50 for those proposed by progovernment DAB legislators and about .20 for opposition Democrats. Additional analysis (available on request) shows that this variation is due to the

20. The parameters also confirm our expectations about the absence of vote trades or side payments. different types of motions offered by each group. Progovernment legislators are more likely to offer noncontroversial motions (such as extolling the virtues of Confucian medicine), while regime opponents are more likely to offer motions dealing with polarizing topics (such as universal suffrage, relations with Beijing, press freedom, or no-confidence motions).

Table 2. Parameters for Analysis of LegCo Enactments

(1)

Type of measure:

\begin{tabular}{lcc} 
Proposed by government & $3.9^{* * *}$ & $4.2^{* * *}$ \\
& $(.76)$ & $(.76)$ \\
Member amendment to proposal & $-2.6^{* * *}$ & $-2.7^{* * *}$ \\
& $(1.05)$ & $(1.0)$ \\
Member amendment to motion & -.22 & -.22 \\
& $(.25)$ & $(.25)$ \\
Other & -.52 & -.63 \\
& $(.51)$ & $(.53)$ \\
roposer: & & \\
(Distance to DAB $)^{2}$ & $-.00045^{* * *}$ & $\ldots$ \\
& $(.000009)$ & \\
Opposition & $\ldots$ & $-.57^{* * *}$ \\
& & $(.20)$ \\
Constant & .03 & -.32 \\
& $(.26)$ & $(.25)$ \\
$\chi^{2}$ & $91.6^{* * *}$ & $61.1^{* * *}$ \\
Pseudo- $R^{2}$ & .29 & .27 \\
\hline
\end{tabular}

Note. Dependent variable: measure enacted. Parameters, with robust standard errors in parentheses. $N=629$. LegCo = Legislative Council; $\mathrm{DAB}=$ Democratic Alliance for the Betterment and Progress of Hong Kong.

$* p<.1$.

${ }^{* *} p<.05$.

${ }^{* * *} p<.01$, all two-tailed. 


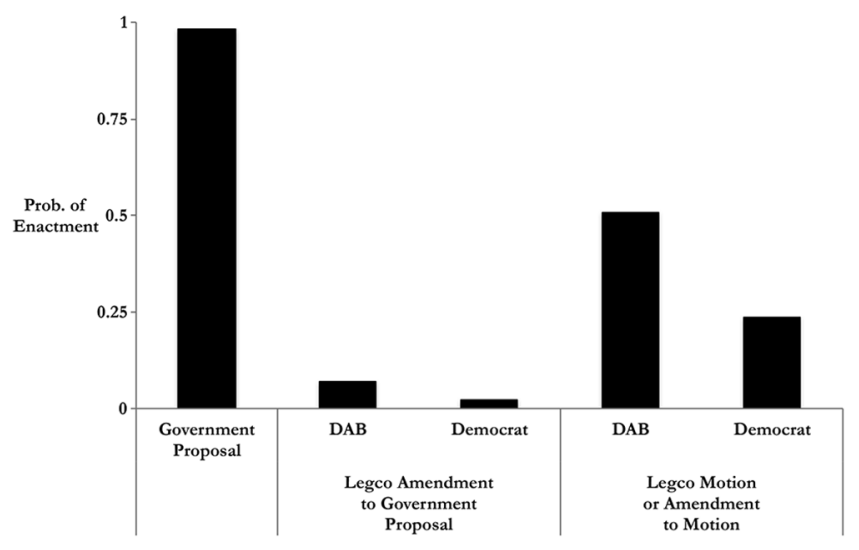

Figure 4. Fate of LegCo legislation

Thus, when motions are voted on, those offered by progovernment legislators are more likely to be successful.

\section{MAINTAINING THE EAR: THE IMPACT OF ELECTORAL CHANGE ON LEGISLATIVE OUTCOMES}

The 2014 protests in HK centered on citizen demands for universal suffrage in light of the government's refusal to carry out commitments to open the nomination process for the office of chief executive. Under the current system, nominees for this office are selected by a 1,200-member Election Council, who are themselves selected by restricted constituencies that resemble FCs. Although it was ultimately rejected by LegCo, the proposed switch to a new nominating committee would essentially guarantee the election of a pro-Beijing chief executive whose actions in office are broadly consistent with existing policy. The government's interest in controlling this process is clear: an open process could lead to electing an anti-Beijing chief executive who could use the government's procedural advantages in the LegCo to offer opposition proposals for a vote, thereby circumventing the regime's veto power and lowering the bar to enacting these proposals from the dual-majority constraint to a chamber majority.

At the same time that these revisions were debated, some progovernment groups suggested new procedures to vet LegCo candidates, wherein bodies similar to the Election Council would decide who could contest FC seats should the electoral base for these seats similarly expand to include the general electorate in the future, presumably to ensure the election of pro-Beijing candidates. At first glance, this move contradicts the core finding of our analysis about the importance of split voting as a control on LegCo outcomes - if this procedure makes it nearly impossible for members to enact significant reforms, why would the government need to impose additional restrictions on who gets elected in the first place?

The answer, paradoxically, is that these proposals reflect the electoral gains by progovernment legislators in GC seats.
In the current LegCo (and in all previous sessions), the preferences of GC and FC legislators are sufficiently different so that no proposal can gain majority support from both groups. As shown in figure 1, however, progovernment forces gained GC seats in the 2012 election while maintaining their majority in FC seats. If this trend continues in future elections, progovernment forces could amass a majority in GC seats, shifting the GC UCS toward the FC UCS such that the two sets overlap-meaning that it would be possible to devise amendments to proposals that garnered majority support from both GC and FC legislators and thus eliminating the regime's position as a veto player. An example is shown in figure 5.

Figure 5 shows UCSs for a simulated LegCo, where the $\mathrm{DAB}$ (independent legislators with ideal points similar to the $\mathrm{DAB}$ ) gains two seats, one from the Civic Party and one from the Democratic Party, with all other GC and FC seats reelecting their incumbents, from the Fifth Session (201216) so that proregime forces hold a narrow 18-17 majority in GC seats and continue their dominance of the FCs. ${ }^{21}$ Figure 5 shows that the DAB's gains translate into a large shift in enactable outcomes: the UCS for the GC moves sharply to the right so that it overlaps a large portion of the FC UCS. In substantive terms, these proregime gains would eliminate the procedural roadblock caused by split voting. As figure 5 shows, given the shift in the GC UCS, some measures would then be enactable - those corresponding to the area where the GC and FC UCSs overlap. In substantive terms, while opposition forces would still be unable to achieve their most preferred outcomes, they could devise amendments to proposals that would attract FC majorities without sacrificing a GC majority. At that point, the regime would be faced with a problematic choice: lose a significant measure of control over LegCo policy outcomes or resort to more draconian tactics, such as curbing the opposition's proposal power, pressuring legislators to vote against these measures, or controlling who is elected to the LegCo in the first place.

These results show that the policy implications of the LegCo's split voting procedure are contingent on electoral outcomes - on the kinds of legislators elected to FC and GC seats. From the government's perspective, the current distribution of seats, in which proregime forces hold the balance of power in FC seats while opposition forces have a narrow margin in GC seats, preserves its status as a veto player in the LegCo. Opposition gains in FC seats would represent an obvious threat to government control, but so

21. Each party's membership has a tight distribution of ideal points, so to create this hypothetical legislature we randomly delete one member of the Civic group and one from the Democrats and duplicate the ideal points of two DAB members. 


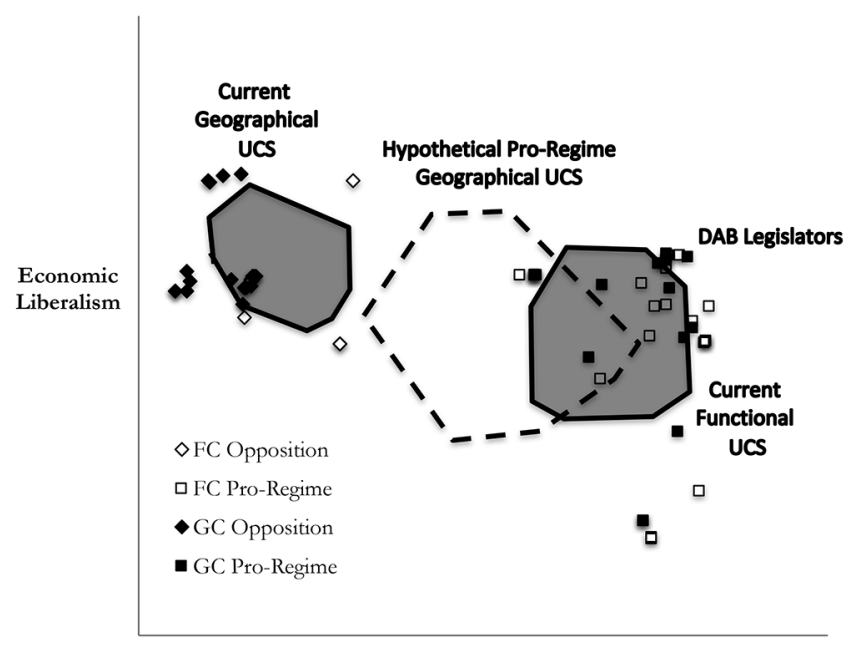

Democracy Preferences

Figure 5. Hypothetical future LegCo

would gains in GC seats by supporters of the regime. While the government did not change LegCo nomination procedures for the upcoming 2016 elections, continued gains by proregime legislators may force them to revisit this decision.

\section{DISCUSSION}

The principle contribution of our article is to move beyond the "E" in EAR to assess the broader representative apparatus in these countries, with an eye to understanding the variation in veto powers held by these regimes and the sources of these powers. The point is that not that all EARs manipulate legislative rules but that ignoring this possibility may give a false sense of an EAR's character. For example, a regime might be seen as more liberal than another if it puts few restrictions on candidacy or party organization. However, these observations leave open the question whether it is possible for the winners of these elections to forge legislative compromises and enact these proposals into law. An EAR's apparent electoral liberalism may be matched by highly restrictive legislative rules. More generally, our results confirm that the representative character of an EAR (or any regime) is not just a function of who gets elected to political office - it also depends on the procedures used to construct the legislative agenda and how these proposals are debated, amended, and decided on.

The need to account for variation in the legislative rules used by different EARs is particularly important because these rules can interact with and magnify the impact of electoral arrangements, creating veto players where none ostensibly exist. For example, HK's electoral system (in particular, the distinction between GCs and FCs) is clearly designed to create a fragmented party system and maximize the number of independent legislators, making it less likely that a prodemoc- racy or opposition-business coalition will emerge to challenge the regime. However, the requirement that member proposals be decided on using split voting vastly increases the impact of these electoral provisions. While these interactive effects are not inevitable (split voting is beneficial to HK's EAR only insofar as GC and FC legislators have distinct policy preferences), the potential for these effects strengthens our argument for examining how EARs manipulate legislative rules to preserve their veto over policy change.

With regard to HK's LegCo, the analysis confirms that the requirement for split voting on all nongovernment measures creates a significant disadvantage for opposition and proregime legislators alike: they must build supermajority coalitions in order to change government policy-coalitions that are extremely difficult to build given the distribution of interests in the chamber. In contrast, LegCo rules give the regime a clear procedural advantage. In fact, in our data, there is only one case of a regime measure (an amendment to a telecommunications bill) being defeated. In this way, split voting is a real-world example of how legislative rules can provide EARs with a crucial second line of defense against both opposition forces and dissident factions within the regime. In that sense, the institutional arrangements in HK are consistent with the Gandhi and Przeworski vision of EAR legislatures as a vehicle for co-opting the opposition.

These findings also suggest why the HK government has strongly resisted attempts to democratize the nomination process for chief executive, as well as its moves to impose controls on LegCo nominations. Up to the 2016 elections, changes to the distribution of LegCo seats (increasing the number of geographical seats and added functional seats that are selected by citizens who are not part of a recognized business or professional group) have been accomplished without negating the effects of split voting. In fact, opposition forces gained GC seats in the 2016 election. However, as the controversy over the legality of the swearing-in of six opposition lawmakers and their subsequent removal from office by the court gave rise to a proregime GC majority following the 2018 by-elections, the regime will seek to redevelop its overall strategy for legislative control. These trends underscore the complex interplay between electoral and legislative institutions that keeps EARs in power, as well as the measures that these regimes must take to preserve their position in light of changes in public opinion and electoral outcomes.

\section{ACKNOWLEDGMENTS}

The authors are grateful for comments from participants in seminars at the Indiana University Ostrom Workshop, Binghamton University, and the University of Hong Kong. 


\section{APPENDIX}

TABLE A1. Hong Kong Legislative Council after 2012 Elections

\begin{tabular}{|c|c|c|}
\hline Type/Constituency & Seats & Votes \\
\hline \multicolumn{3}{|l|}{ Geographical: } \\
\hline Hong Kong Island & 7 & 330,766 \\
\hline Kowloon West & 5 & 232,081 \\
\hline Kowloon East & 5 & 284,782 \\
\hline New Territories West & 9 & 498,610 \\
\hline New Territories East & 9 & 464,745 \\
\hline \multicolumn{3}{|l|}{ Functional (contested): } \\
\hline District council & 5 & $1,591,872$ \\
\hline Agricultural and fisheries & 1 & 133 \\
\hline Education & 1 & 61,705 \\
\hline Legal & 1 & 4,498 \\
\hline Accountancy & 1 & 16,470 \\
\hline Medical & 1 & 6,746 \\
\hline Health services & 1 & 22,867 \\
\hline Engineering & 1 & 6,780 \\
\hline Architectural, surveying, and planning & 1 & 4,739 \\
\hline Social welfare & 1 & 10,191 \\
\hline Tourism & 1 & 926 \\
\hline Financial services & 1 & 465 \\
\hline Textiles and garment & 1 & 1,931 \\
\hline Information technology & 1 & 4,891 \\
\hline Functional (uncontested) & \multicolumn{2}{|c|}{$\begin{array}{l}\text { Rural, insurance, transport, labor (3), real } \\
\text { estate and construction, industrial (2), } \\
\text { commercial (2), finance, import and } \\
\text { export, wholesale and retail, catering }\end{array}$} \\
\hline
\end{tabular}

Source. Government of Hong Kong, http://www.elections.gov.hk/LegCo2012/eng/results.html (accessed October 22, 2014).

TABLE A2. Seat Allocations in the Hong Kong Legislative Council, 1998-Present

\begin{tabular}{|c|c|c|c|c|}
\hline \multirow[b]{2}{*}{ Council (Term of Office) } & \multirow[b]{2}{*}{ Geographical Constituencies } & \multicolumn{2}{|c|}{ Functional Constituencies } & \multirow[b]{2}{*}{ Electoral Committee } \\
\hline & & Business Groups & District Council & \\
\hline First Council (7/1998-10/2000) & 20 & 30 & $\cdots$ & 10 \\
\hline Second Council (10/2000-10/2004) & 24 & 30 & $\cdots$ & 6 \\
\hline Third Council (10/2004-10/2008) & 30 & 30 & $\ldots$ & $\ldots$ \\
\hline Fourth Council (10/2008-10/2012) & 30 & 30 & $\cdots$ & $\cdots$ \\
\hline Fifth Council (10/2012-10/2016) & 35 & 30 & 5 & $\cdots$ \\
\hline Sixth Council (10/2016-10/2020) & 35 & 30 & 5 & $\cdots$ \\
\hline
\end{tabular}

Source. "History of the Legislature," http://www.LegCo.gov.hk/general/english/intro/hist_lc.htm (accessed April 19, 2019). 


\section{REFERENCES}

Bateman, David A., and John Lapinski. 2016. "Ideal Points and American Political Development: Beyond DW-NOMINATE." Studies in American Political Development 30 (2): 147-71.

Bianco, William T., Ivan Jeliaskov, and Itai Sened. 2004. "The Uncovered Set and the Limits of Legislative Action." Political Analysis 12 (3): 256-76.

Bianco, William T., Christopher Kam, Ital Sened, and Regina Smyth. 2015. "The Uncovered Set and Its Applications." In Jac C. Heckelman and Nicholas Miller, eds., Elgar Handbook of Social Choice and Voting. Northampton, MA: Elgar.

Bianco, William T., Michael Lynch, Gary Miller, and Itai Sened. 2006. “A Theory Waiting to be Discovered and Used: A Reanalysis of Canonical Experiments on Majority Rule Decision Making." Journal of Politics 68 (4): 837-50.

Bianco, William T., Michael Lynch, Gary Miller, and Itai Sened. 2008. "The Constrained Instability of Majority Rule: Experiments on the Robustness of the Uncovered Set." Political Analysis 16 (2): 115-37.

Boix, Carles, and Milan W. Svolik. 2013. "The Foundations of Limited Authoritarian Government: Institutions, Commitment, and PowerSharing in Dictatorships." Journal of Politics 75 (2): 300-316.

Brownlee, Jason. 2007. Authoritarianism in an Age of Democratization. New York: Cambridge University Press.

Chan, Wilfred. 2016. "Hong Kong Legislators Reject China-Backed Reform Bill.” CNN, June 18. http://edition.cnn.com/2015/06/18/asia/hong-kong -reform-vote/index.html.

Cox, Gary. 1987. “The Uncovered Set and the Core.” American Journal of Political Science 31 (2): 408-22.

Duggan, John. 2006. "Endogenous Voting Agendas." Social Choice and Welfare 27 (3): 495-530.

Fish, M. Steven, and Matthew Kroenig. 2006. The Legislative Powers Survey and Parliamentary Powers Index. New York: Cambridge University Press.

Gamm, Gerald, and John Huber. 2002. "Legislatures as Political Institutions: Beyond the Contemporary Congress." In Ira Katznelson and Helen V. Milner, eds., Political Science: State of the Discipline. New York: Norton, 313-41.

Gandhi, Jennifer. 2008. Political Institutions under Dictatorship. Cambridge: Cambridge University Press.

Gandhi Jennifer, and Adam Przeworski. 2007. "Authoritarian Institutions and the Survival of Autocrats." Comparative Political Studies 40 (11): 1279-301.

Gates, Scott, Benjamin Graham, Yonatan Lupu, Havard Strand, and Kaare Strom. 2016. "Power Sharing, Protection, and Peace." Journal of Politics 78 (2): 512-26.

Geddes, Barbara. 1999. "What Do We Know about Democratization after 20 Years?” Annual Review of Political Science 2:115-44

Geddes, Barbara. 2005. "Why Parties and Elections in Authoritarian Regimes?" Paper presented at the annual meeting of the American Political Science Association, Washington, DC.

Jeong, Gyung-Ho, Gary J. Miller, and Itai Sened. 2009. "Closing the Deal: Negotiating Civil Rights Legislation.” American Political Science Review 103 (4): 588-606.

Kam, Christopher, William Bianco, Itai Sened, and Regina Smyth. 2010. "Ministerial Selection and Intraparty Organization in the Contemporary British Parliament." American Political Science Review 104 (2): 289-306.

Lau, Siu-kai, and Hsin-chi Kuan. 2000. "Partial Democratization, 'Foundation Moment' and Political Parties in Hong Kong." China Quarterly 163:705-20.

Lau, Siu-kai, and Hsin-chi Kuan. 2002. "Hong Kong's Stunted Political Party System.” China Quarterly 172:1010-28.
Legislative Council Secretariat. 2008. "Legislative Council Procedures on Members' Bills.” Legislative Council, January 3. http://www.LegCo.gov .hk/general/english/bills/mem-bill.pdf (accessed August 10, 2014).

Leung, Kwan-kwok. 1997. "Fractionalization of the 'Party' System in the Hong Kong Transition.” In Kwan-kwok Leung and Kam-yee Law, eds., Political Order and Power Transition in Hong Kong. Hong Kong: Chinese University Press, 53-78.

Levitsky, Steven, and Lucan Way. 2002. "The Rise of Competitive Authoritarianism." Journal of Democracy 13 (2): 51-65.

Loh, Christine. 2006. Functional Constituencies: A Unique Feature of the Hong Kong Legislative Council. Hong Kong: Hong Kong University Press.

Ma, Ngok. 2007. “The Legislature.” In Ngok Ma, Political Development in Hong Kong: State, Political Society, and Civil Society. Hong Kong: Hong Kong University Press, 97-133.

Ma, Ngok. 2011. "Hong Kong's Democrats Divide.” Journal of Democracy 22 (1): 54-67.

Ma, Ngok, and Chi-keung Choy. 1999. "The Evolution of the Electoral System and Party Politics in Hong Kong." Issues and Studies 35 (1): 167-94.

Ma, Ngok, and Chi-keung Choy. 2003. "The Impact of Electoral Rule Change on Party Campaign Strategy: Hong Kong as a Case Study.” Party Politics 9 (3): 347-67.

Magaloni, Beatriz. 2008. "Credible Power-Sharing and the Longevity of Authoritarian Rule." Comparative Political Studies 41 (4/5): 71541.

McKelvey, Richard D. 1986. "Covering Dominance and Institution Free Properties of Social Choice." American Journal of Political Science 30 (2): 283-314

Miller, Nicholas. 1980. "A New Solution Set for Tournaments and Majority Voting." American Journal of Political Science 24 (1): 68-96.

Ortmann, Stephan. 2015. "The Umbrella Movement and Hong Kong's Protracted Democratization Process.” Asian Affairs 46 (1): 32-50.

Penn, Elizabeth Maggie. 2009. "A Distributive N-Amendment Game with Endogenous Agenda Formation.” Public Choice 136 (1/2): 201-13.

Poole, Keith. 2000. "Non-parametric Unfolding of Binary Choice Data." Political Analysis 8 (3): 211-37

Ramady, Mohamed. 2013. Political, Economic, and Financial Country Risk. New York: Springer.

Scott, Ian. 2000. “The Disarticulation of Hong Kong's Post-handover Political System." China Journal 43:29-53.

Scott, Ian. 2007. "Legitimacy, Governance and Public Policy in Posthandover Hong Kong." Asia Pacific Journal of Public Administration 29 (1): 29-49.

Shepsle, Kenneth A., and Barry R. Weingast. 1984. "Uncovered Sets and Sophisticated Voting Outcomes with Implications for Agenda Institutions." American Journal of Political Science 28 (1): 49-74.

Sing, Ming, and Yuen-sum Tang. 2012. "Mobilization and Conflicts over Hong Kong's Democratic Reform.” In Wai-man Lam and Percy Luentim Lui, eds., Contemporary Hong Kong Government and Politics. 2nd ed. Hong Kong: Hong Kong University Press, 137-54.

Smyth, Regina, William Bianco, Christopher Kam, and Itai Sened. 2011. "Explaining Transitional Representation: The Rise and Fall of Women of Russia." Journal of East European and Asian Studies 2 (1): 137-62.

Spriling, Arthur, and Iain McLean. 2006. "UK OC OK? Interpreting Optimal Classification Scores for the U.K. House of Commons." Political Analysis 15 (1): 85-96.

Strøm, Kaare W., Scott Gates, Benjamin A. T. Graham, and Håvard Strand. 2016. "Inclusion, Dispersion, and Constraint: Powersharing in the World's States, 1975-2010." British Journal of Political Science 47 (1): 165-85. 
Svolik, Milan W. 2012. The Politics of Authoritarian Rule. New York: Cambridge University Press.

Truex, Rory. 2013. "The Returns to Office in a 'Rubber Stamp' Parliament." American Political Science Review 108 (2): 235-51.

Tsebelis, George. 2002. Veto Games: How Political Institutions Work. Princeton, NJ: Princeton University Press.

Tsebelis, George, and Jennifer Money. 1997. Bicameralism. New York: Cambridge University Press.
Wintrobe, Ronald. 1998. The Political Economy of Dictatorship, vol. 6. Cambridge: Cambridge University Press.

Wright, Joseph. 2008. "Do Authoritarian Institutions Constrain? How Legislatures Affect Economic Growth and Investment." American Journal of Political Science 52 (2): 322-34.

Young, Simon, and Anthony Law. 2004. A Critical Introduction to Hong Kong's Functional Constituencies. Hong Kong: Civic Exchange. 
Copyright of Journal of Politics is the property of The Southern Political Science Association and its content may not be copied or emailed to multiple sites or posted to a listserv without the copyright holder's express written permission. However, users may print, download, or email articles for individual use. 